\title{
A EDUCAÇÃO COMO FATOR DE TRANSFORMAÇÃO NO MERCADO DE TRABALHO FEMININO
}

\author{
AUTOR: JAMILE DANTAS DA SILVA \\ CO-AUTOR/ORIENTADOR: CAROLINA BESSA FERREIRA DE OLIVEIRA
}

\begin{abstract}
Resumo: O presente trabalho se insere no Grupo de Pesquisa em Desigualdades e Efetividades de Políticas Públicas para Direitos Sociais (GEPEDESE) e teve início em fevereiro de 2020, após desistência da estudante que iniciou as atividades em 2019. Com os objetivos de abordar e discutir os conceitos de classe, raça, gênero, divisão sexual do trabalho e interseccionalidade e investigar a correlação entre os direitos ao trabalho e à educação na desigualdade que acometem a mulher negra na sociedade brasileira, é uma pesquisa descritiva, cujo processo foi aprofundado em discussões de autoras como Stamatto, Davis, Scott e Federici, além de legislação e indicadores sobre educação e mercado de trabalho feminino no Brasil. Uma de suas etapas seria a aplicação de questionários direcionado ás alunas das escolas públicas de Ensino Médio de Porto Seguro, mas não foi possível pois no mês de março iniciou o afastamento social em decorrência do Covid-19, razão pela qual a pesquisa focou na revisão bibliográfica. As relações de gênero têm o trabalho como uma de suas estruturas, designa a mulher ao espaço doméstico, não trata essa função como trabalho, tornando-o pouco ou não remunerado. As mulheres são as principais responsáveis pelo trabalho doméstico, dedicam, segundo dados do IBGE (2018), cerca de 18,1 horas semanais aos cuidados de pessoas e/ou afazeres domésticos por pessoas ocupadas contra 10,5 h dos homens. Mulheres pretas ou pardas dedicam 18,6 horas contra 17,7h das brancas. No ensino médio as mulheres representam $73,5 \%$ e homens $63,2 \%$, entretanto, há considerável desigualdade entre brancas e pretas ou pardas, evidenciando que a cor ou raça é fator preponderante na desvantagem educacional. De acordo com dados do IPEA (2019), a saída das jovens mulheres da ocupação do trabalho doméstico é mais intensa para as brancas do que para as negras, visto que contam com maiores níveis de escolaridade e as oportunidades de emprego tendem a se abrir com maior frequência. Diante disso, nota-se a importância de entender que a desigualdade na distribuição do trabalho doméstico e no acesso à educação, historicamente, é uma das estruturas do patriarcado e é necessário situar as discussões a partir da perspectiva interseccional, vez que os desdobramentos dessas desigualdades se manifestam de maneira incisiva em relação às mulheres pobres e negras. Por fim, cumpre destacar que o acesso à educação se manifesta como alicerce para as conquistas das mulheres, principalmente no mercado de trabalho.
\end{abstract}

Palavras-chave: Trabalho Doméstico, Interseccionalidade, Raça, Gênero, Educação. 